\title{
What affects the nitrogen retention in Tatra Mountains lakes' catchments in Poland?
}

\author{
D. Rzychoń and A. Worsztynowicz \\ Institute for Ecology of Industrial Areas, 6 Kossutha str., 40-844 Katowice, Poland \\ Received: 2 November 2006 - Published in Hydrol. Earth Syst. Sci. Discuss.: 11 September 2007 \\ Revised: / - Accepted: / - Published: 5 March 2008
}

\begin{abstract}
The study of acidification and recovery of two lakes situated in the Polish Tatra Mountains, exposed to similar deposition of acidic substances but differing in altitude, catchment morphology, hydrology, and biodiversity is presented. Measurements were performed in 1992-1996 and 2001-2005. Simultaneously, research on the atmospheric deposition was carried out. The following physical and chemical parameters in lake water and precipitation were measured: $\mathrm{pH}$, conductivity $\left(\mathrm{K}_{25}\right), \mathrm{Ca}^{2+}, \mathrm{Mg}^{2+}, \mathrm{Na}^{+}, \mathrm{K}^{+}, \mathrm{NH}_{4}^{+}$, $\mathrm{SO}_{4}^{2-}, \mathrm{NO}_{3}^{-}, \mathrm{Cl}^{-}$and alkalinity. Distinct changes in the chemical composition of precipitation were observed over 14 years (1992-2005). During this time the sulphate concentration decreased significantly, and the concentration of hydrogen ions in precipitation decreased at an average rate of $2.23 \mathrm{meq} / \mathrm{m}^{3} / \mathrm{yr}$. There was no significant change in nitrate, ammonium or total nitrogen deposition. The chemical composition of water of both lakes changed significantly and showed signs of chemical recovery with decreases in sulphate concentration and increases in acid neutralising capacity. The concentration of base cations declined. Despite the lack of clear trends in nitrogen deposition, a statistically significant drop in concentration was observed in the two lakes. A significant increase of about $15 \%$ in the retention of nitrogen compounds in both catchments occurred. An improvement in nitrogen saturation status in both catchments was observed. This probably resulted mainly from decreasing acidification and global warming which prolongs the vegetative period, changes plant species composition and increases the microbiological activity of soil.
\end{abstract}

\section{Introduction}

In the 1980's the emissions of sulphur (S) and nitrogen (N) compounds in Europe began to decrease. S compounds de-

Correspondence to: D. Rzychoń

(rzychon@ietu.katowice.pl) creased by $50-85 \%$ and $\mathrm{N}$ compounds by $0-30 \%$. The results from the international UNECE monitoring program ICP Waters show widespread improvement in surface water quality in response to decreasing acidic deposition in the years 1990-2001. The most significant change was a decrease in sulphate $\left(\mathrm{SO}_{4}^{2-}\right)$ concentrations while nitrate $\left(\mathrm{NO}_{3}^{-}\right)$concentrations were unchanged in most of regions examined (Skjelkvåle et al., 2005). The extent of recovery from acidification in Europe and North America has varied over time, between regions and between sites within regions, depending on the range of factors including the magnitude of deposition change and catchment characteristics (Skjelkvåle et al., 2005).

Relatively fast reversal of changes connected with acidification was documented by Gunn (1995) for waters of the heavily contaminated region of Sudbury, Ontario (Canada) and by Veselý et al. (1998) for lakes in the Bohemian Forest (Czech Republic). Nevertheless, many rivers and lakes showed a rather slow increase in $\mathrm{pH}$ and acid neutralising capacity (ANC), often because of simultaneous decrease in base cations and strong acid anions (Stoddard et al., 2000).

Variability in the ecosystems' response to changing acid deposition makes the estimation of potential recovery difficult. Values and trends of the key soil and water parameters, dependent on deposition of acidifying substances are a result of complex processes occurring in the catchment. Among factors affecting the chemical changes in the catchment's soil and water are changes in the $\mathrm{N}$ transformation cycle, e.g., an increase in $\mathrm{N}$ uptake by plants and soil micro-organisms (Veselý et al., 2002, 2003). Recently, global climatic changes have been taken into consideration as factors possibly influencing the process of recovery (Dillon et al., 2003). Among factors causing delays in the recovery of acidified surface waters are: (1) significant increase in the frequency of episodes of high deposition of sea salt (Evans and Monteith, 2002); (2) changes in surface water hydrology resulting on the one hand from more frequent dry weather periods and on the

Published by Copernicus Publications on behalf of the European Geosciences Union. 


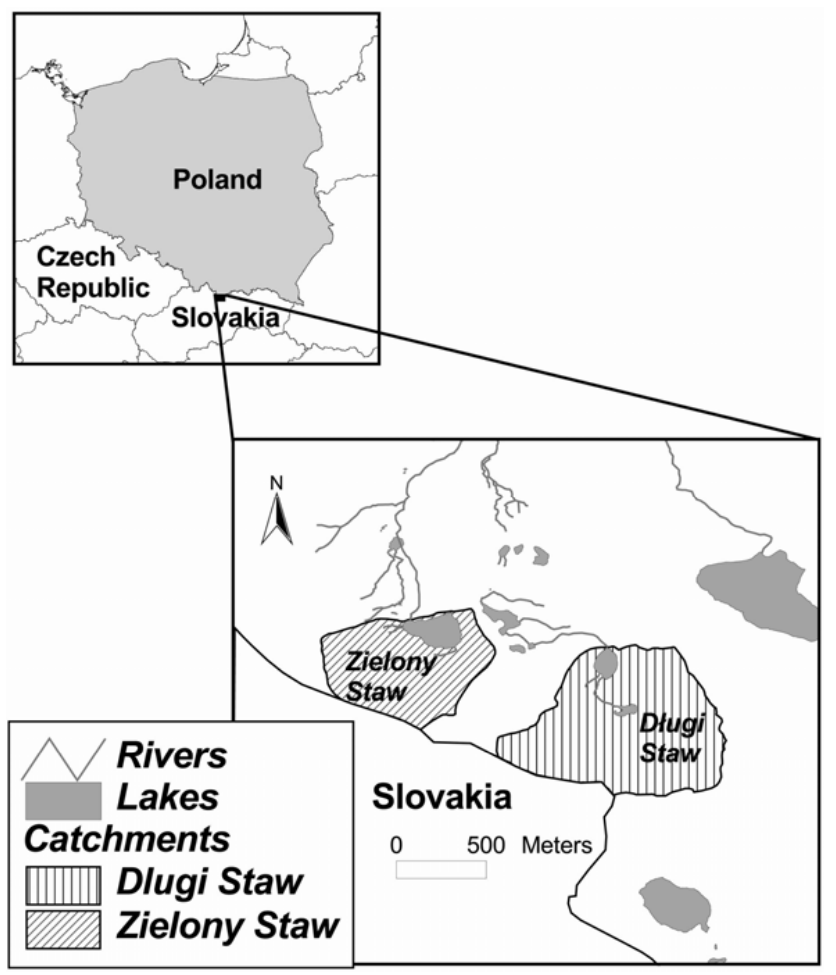

Fig. 1. Location of the Tatra Mountains and the study area.

other hand increased frequency and intensity of precipitation; (3) increase of concentrations of dissolved organic carbon (DOC) in some regions (Davies et al., 2005); and (4) disturbances in natural processes that increase ANC of surface waters, such as $\mathrm{SO}_{4}^{2-}$ reduction, denitrification, ion exchange with bottom sediment and organic acid decomposition. Among phenomena favourable to surface water recovery are: (1) decreases in aluminium $(\mathrm{Al})$ ion concentration because of a decrease in $\mathrm{Al}$ compound solubility as a result of temperature increase (Veselý et al., 2003); (2) increased rate of base cation weathering, also connected with the temperature increase; (3) higher than generally expected $\mathrm{N}$ retention in many catchments, and (4) episodes of alkaline deposition of particulate matter from the Sahara Desert, which is particularly important in high mountain areas in Europe (Rogora et al., 2003).

This paper presents results of a study of acidification in the two Tatra lakes carried out between 1992 and 2005. Within this time significant changes in the emission of $\mathrm{S}$ and $\mathrm{N}$ compounds to the atmosphere were observed. Reduction of sulphur oxide emissions from the territory of Poland in the period of 1980-2003 is estimated to be about $66 \%$, nitrogen oxide emission reduction of about $34 \%$, and ammonia about $41 \%$ (EMEP, 2005). Subsequently, deposition of acidifying substances from the atmosphere decreased. These changes were accompanied by changes in temperature and precipitation. Results of analysis of lake water provide a good mate-
Table 1. Morphological and hydrological parameters of the studied Tatra lakes (Szafer et al., 1962; Rzychoń, 1998).

\begin{tabular}{lccc}
\hline Lake & Unit & Zielony Staw & Dlugi Staw \\
\hline Altitude & $\mathrm{m}$ a.s.l. & 1672 & 1784 \\
Surface lake area & $\mathrm{ha}$ & 3.84 & 1.59 \\
Depth max. & $\mathrm{m}$ & 15.1 & 10.6 \\
Volume & $10^{3} \mathrm{~m}^{3}$ & 290 & 81 \\
Catchment surface area & $\mathrm{ha}$ & 37.2 & 62.6 \\
Retention time & $\mathrm{yr}$ & 0.54 & 0.09 \\
Annual precipitation & $\mathrm{m} \mathrm{yr}^{-1}$ & 1.67 & 1.67 \\
Runoff* & $\mathrm{m} \mathrm{yr}^{-1}$ & 1.43 & 1.43 \\
\hline
\end{tabular}

* The annual mean values of runoff calculated assuming the runoff coefficient (runoff/precipitation) as equal to 0.86 (Łajczak, 1980, 1988).

rial for the assessment of the impact of these changes on the Tatra lake catchments, with a special focus on changes in the $\mathrm{N}$ and $\mathrm{S}$ budgets and the $\mathrm{N}$ cycle.

\section{Materials and methods}

\subsection{Site}

The Tatra Mountains are situated at the border between Poland and Slovakia (Fig. 1). It is a mountain ridge $53 \mathrm{~km}$ long and $18 \mathrm{~km}$ wide, with the highest summit of $2663 \mathrm{~m}$ a.s.l. in Slovakia, and $2499 \mathrm{~m}$ a.s.l. in Poland. Within the Karpaty formation, the Tatra Mountains create the highest mountain massif, the characteristic feature of which is a young glacial terrain. Due to very high elevation, low air temperatures and high precipitation are typical of the Tatra Mountains. Another distinctive feature of the region is frequent, strong winds, which transport dusts and pollutants. The study area focussed on the part of the Polish Tatra Mountains with crystalline core where the ionic strength of surface waters is very low, resulting in high sensitivity to acid deposition. The selected lakes, Dlugi Staw and Zielony Staw, are located in the area of Hala Gsienicowa. They differ in morphological and hydrological characteristics (Table 1) as well as in intensity of biological processes occurring in their catchments and water. Zielony Staw is a headwater lake while Dlugi Staw has a small pond upstream (Fig. 1).

The catchments of Dlugi Staw and Zielony Staw are characterised by steep slopes. The major part of the catchment consists of rocks, moraine, stone rubble, talus with lichen the dominant plant. The following factors contribute to the podsolic character of the soil-forming process in the Tatra Mountains (Skiba, 1977): acid carbonate-free matrix (Tatra granitoid), acidophilic vegetation and intensive precipitation. The intensity of podsolic processes in the Tatra Mountains is characterized by zonality due to climate and biological 
Table 2. Land cover in the catchments.

\begin{tabular}{lcc}
\hline Type & \multicolumn{2}{c}{ \% of the catchment area } \\
\hline & Zielony Staw & Dlugi Staw \\
\hline Forest (dwarf pine) & 4.2 & 0 \\
Meadows & 37.7 & 20.2 \\
Moraine & 27.2 & 42.8 \\
Bare rocks & 21.2 & 34.1 \\
Lake & 9.7 & 2.8 \\
\hline
\end{tabular}

differences connected with altitude. In upper locations, like that of the two lakes, mechanical weathering processes and accumulation of organic substances can be observed. Soils occurring in this region include various forms of podsolic rankers and lithosols, the morphology of which reflects the impact of severe climate. Their thickness does not exceed $15 \mathrm{~cm}$. Only very small parts of the catchments are covered with plants. The land use distribution in the catchments was determined using TPN Atlas (Trafas, 1985), photographs and field observations (Table 2).

The study lakes are oligotrophic. Greater fauna biodiversity found in Zielony Staw is probably a result of its slightly higher trophic status (Kownacki et al., 2000). Fish (brook trout) artificially introduced into both lakes in the 1950's have survived only in Zielony Staw.

\subsection{Monitoring}

\subsubsection{Lake water chemistry}

The chemical composition of water of both lakes was monitored in two time periods: 1992-1996 and 2001-2005. Samples of lake outflow were collected fortnightly. The following physical and chemical parameters were measured: $\mathrm{pH}$, conductivity $\left(\mathrm{K}_{25}\right), \mathrm{Ca}^{2+}, \mathrm{Mg}^{2+}, \mathrm{Na}^{+}, \mathrm{K}^{+}, \mathrm{NH}_{4}^{+}, \mathrm{SO}_{4}^{2-}$, $\mathrm{NO}_{3}^{-}, \mathrm{Cl}^{-}$, alkalinity. Analyses for the period 1992-1996 were performed at the Norwegian Institute for Water Research (NIVA) and for 2001-2005 at the Institute for Ecology of Industrial Areas (IETU). Acid neutralising capacity (ANC) was defined as the equivalent sum of base cations $\left(\mathrm{Ca}^{2+}+\mathrm{Mg}^{2+}+\mathrm{Na}^{+}+\mathrm{K}^{+}\right)$minus the equivalent sum of strong acid anions $\left(\mathrm{SO}_{4}^{2-}+\mathrm{NO}_{3}^{-}+\mathrm{Cl}^{-}\right)$.

\subsubsection{Deposition data}

Atmospheric deposition was monitored during the period 1992-2005 with a one-year break in 1998. Data for 19921997 came from IETU studies carried out at the Institute of Meteorology and Water Management station located on Hala Gasienicowa where weekly bulk precipitation was collected. Data for 1999-2005 were provided by the National Deposition Monitoring station initiated in 1999 at Kasprowy Wierch and consisted of monthly bulk precipitation. The stations are

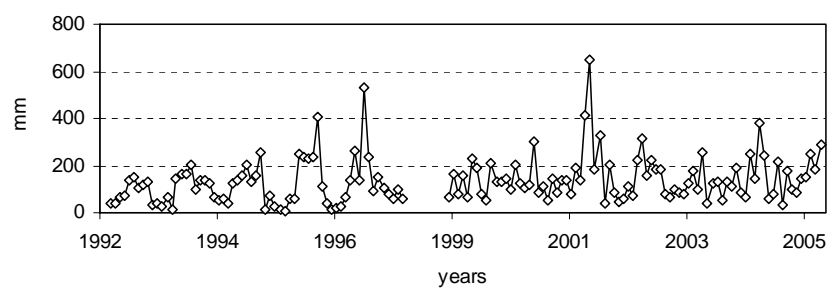

Fig. 2. Monthly precipitation volume in the study area.

located close to each other and to the study lakes. A comparison showed only negligible differences in results between the two stations. In mass balance calculations and statistical analysis deposition data from two time periods: 1992-1996 and 2001-2005 were used.

\subsubsection{Climate data}

Pertinent climate data (daily mean temperature and monthly precipitation) were obtained from the Institute of Meteorology and Water Management (IMGW).

\subsubsection{Trend analysis}

For the trend analysis the Seasonal Kendall Test (SKT), a version of a non-parametric Mann-Kendall test, modified to deal seasonality of the data, was used. The slopes of individual trends were determined using the Sen slope estimator. This method is robust against outliers and missing data, and does not demand a normal distribution of the data (Helsel et al., 1992).

\section{Results}

\subsection{Climate}

In Poland the increase in temperature since the beginning of the twentieth century has been estimated to be $0.6-0.8^{\circ} \mathrm{C} / 100$ years (IMGW, 2005). The decade of the 1990s was the hottest decade of the twentieth century. Trends of climate change in the Polish Tatra Mountains indicate similar relationships as the rest of the country (Niedźwiedź, 1996; Obrȩbska-Starklowa et al., 1996). Analysis of observed and reconstructed summer temperature in the Tatra Mountains from 1550 to 2004 (Niedźwiedź, 2005) indicates that the last cool period was observed in the years 1960-1990. Warm summer seasons have dominated in the Tatra Mountains since 1991. During the past 14 years (1991-2004) only two summers stand out due to their small negative anomalies in temperature: $1993\left(\mathrm{dt}=-0.8^{\circ} \mathrm{C}\right)$ and $1996\left(\mathrm{dt}=-0.3^{\circ} \mathrm{C}\right)$. In 1992-2005 in the meteorological station located on Hala Gasienicowa, near the investigated area, the average annual temperature was $2.8^{\circ} \mathrm{C}$, whereas during the first research 
418 D. Rzychoń and A. Worsztynowicz: What affects the nitrogen retention in Tatra Mountains lakes' catchments in Poland?

Table 3. Trends in precipitation chemistry in the Tatras for the period 1992-2005.

\begin{tabular}{ccc}
\hline Parameter & $\begin{array}{c}\text { Median slope } \\
{\left[\mathrm{meq} / \mathrm{m}^{3} \text { year }\right]}\end{array}$ & Significance level $\mathrm{p}$ \\
\hline $\mathrm{Ca}^{2+}+\mathrm{Mg}^{2+}$ & +0.963 & $<0.01$ \\
$\mathrm{SO}_{4}^{2-}$ & -1.91 & $<0.01$ \\
$\mathrm{NO}_{3}^{-}$ & -0.238 & n.s. \\
$\mathrm{NH}_{4}^{+}$ & +0.360 & n.s. \\
$\mathrm{N}\left(\mathrm{NO}_{3}^{-}+\mathrm{NH}_{4}^{+}\right)$ & +0.05 & n.s. \\
$\mathrm{H}^{+}(1992-1996)$ & +0.616 & $<0.01$ \\
$\mathrm{H}^{+}(2001-2005)$ & -0.212 & $<0.01$ \\
$\mathrm{H}^{+}(1992-2005)$ & -2.23 & $<0.01$ \\
\hline
\end{tabular}

*n.s. - not significant
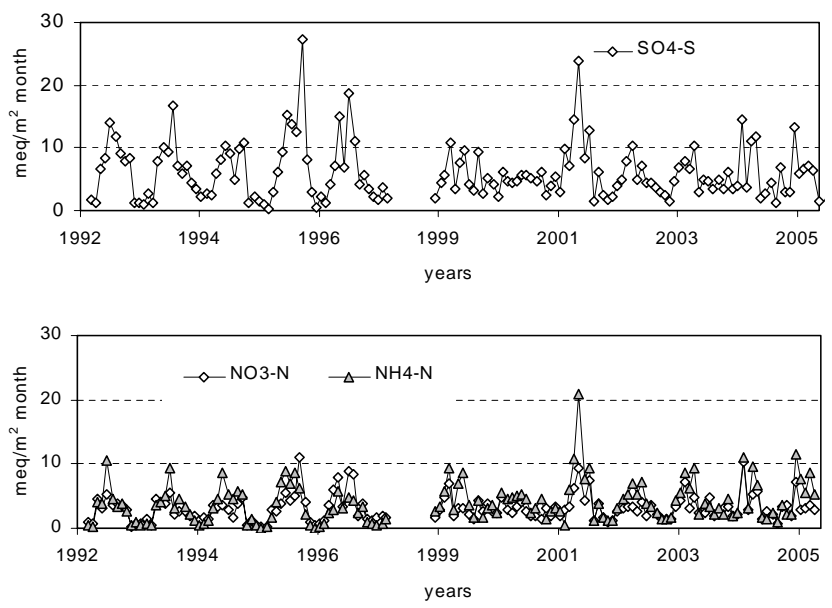

Fig. 3. Monthly inputs of $\mathrm{SO}_{4}^{2-}, \mathrm{NO}_{3}^{-}$, and $\mathrm{NH}_{4}^{+}$by wet deposition in the study area.

campaign (1992-1996) the average temperature was $2.7^{\circ} \mathrm{C}$ and during the second one (2000-2005), 3.0 ${ }^{\circ} \mathrm{C}$.

In recent years the precipitation pattern in Poland has changed; monthly means are maintained by $2-3$ heavy rainfalls whereas in the remaining period symptoms of drought can be observed. The number of extreme events has also increased (IMGW, 2005). The study area shows great variability in the annual precipitation volumes. Total monthly precipitation in the study area in the years 1992-2005 is illustrated in Fig. 2. In the first measurement period, which was characterised by low precipitation total in comparison to the long-term annual average, lower precipitation level was observed in winter and higher in summer (maximum in June in all measured years). These results are consistent with long-term tendencies for the investigated area. Approximately $68.8 \%$ of the precipitation volume came from May to October and 31.2\% from November to April (Szafer et al., 1962). The period of 2000-2005 showed significantly more variability in precipitation volume connected with seasons of the year.
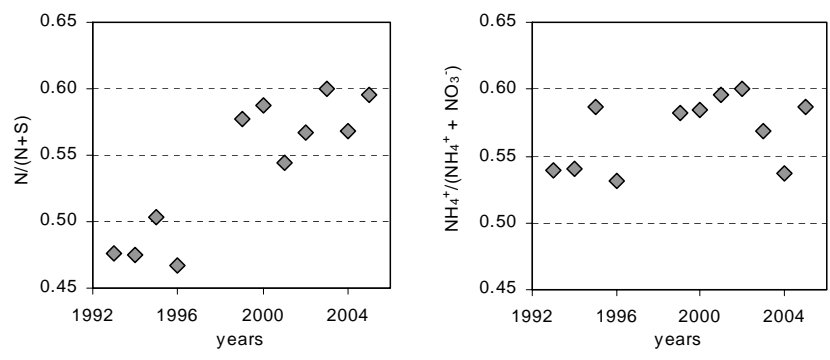

Fig. 4. Nitrogen deposition expressed as fraction of $\mathrm{N}+\mathrm{S}$ deposition (left) and ammonium deposition as fraction of ammonium plus nitrate deposition (right).

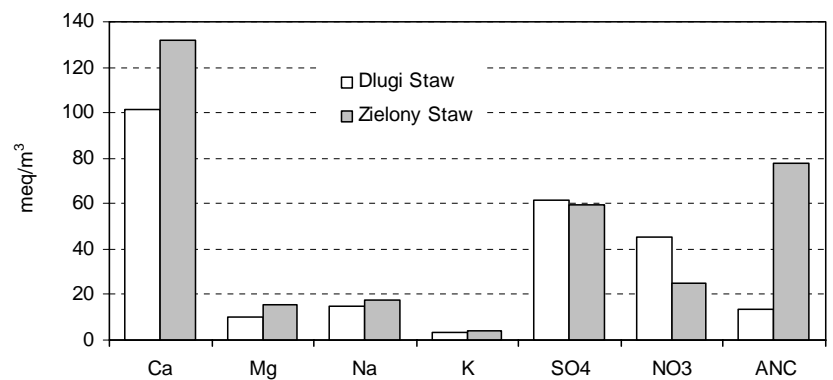

Fig. 5. Volume-weighted annual mean concentrations of major chemical compounds in lake outflow from the two Tatra Mountain lakes, Dlugi Staw and Zielony Staw, for the years 1992-2005.

\subsection{Deposition}

The deposition of $\mathrm{S}$ and $\mathrm{N}$ compounds in the study area was similar to that in many other regions experiencing acidification of freshwaters. During the research period average annual concentration of $\mathrm{SO}_{4}^{2-}$ ranged from $34.2 \mathrm{meq} / \mathrm{m}^{3}$ (2002) to $75.9 \mathrm{meq} / \mathrm{m}^{3}$ (1993); concentrations of $\mathrm{NO}_{3}^{-}$from $17.9 \mathrm{meq} / \mathrm{m}^{3}$ (2002) to $31.8 \mathrm{meq} / \mathrm{m}^{3}$ (1993) and concentrations of $\mathrm{NH}_{4}^{+}$from $17.3 \mathrm{meq} / \mathrm{m}^{3}$ (1997) to $37.4 \mathrm{meq} / \mathrm{m}^{3}$ (2003). At the same time the precipitation $\mathrm{pH}$ varied from 4.39 in 1996 to 5.16 in 2002.

Within the 14-year period distinct changes were observed in the chemical composition of precipitation. The $\mathrm{SO}_{4}{ }^{2-}$ concentration decreased markedly. The concentration of hydrogen ions decreased with an average rate of $2.23 \mathrm{meq} / \mathrm{m}^{3} / \mathrm{yr}$ during the entire period, with a slight increase in 1992-1996 and a slight decrease in 2001-2005. Less pronounced were changes in concentrations of nitrogen compounds (Table 3 ).

Changes in the seasonal precipitation pattern resulted in similar changes in deposition pattern. In 2001-2005 rainfalls and snowfalls were distributed less regularly in winter and summer months than in previous years (Fig. 3). There was a distinct increase in $\mathrm{N} /(\mathrm{N}+\mathrm{S})$ ratio in the deposition and smaller increase in proportion of ammonium in total $\mathrm{N}$ deposition (Fig. 4). 

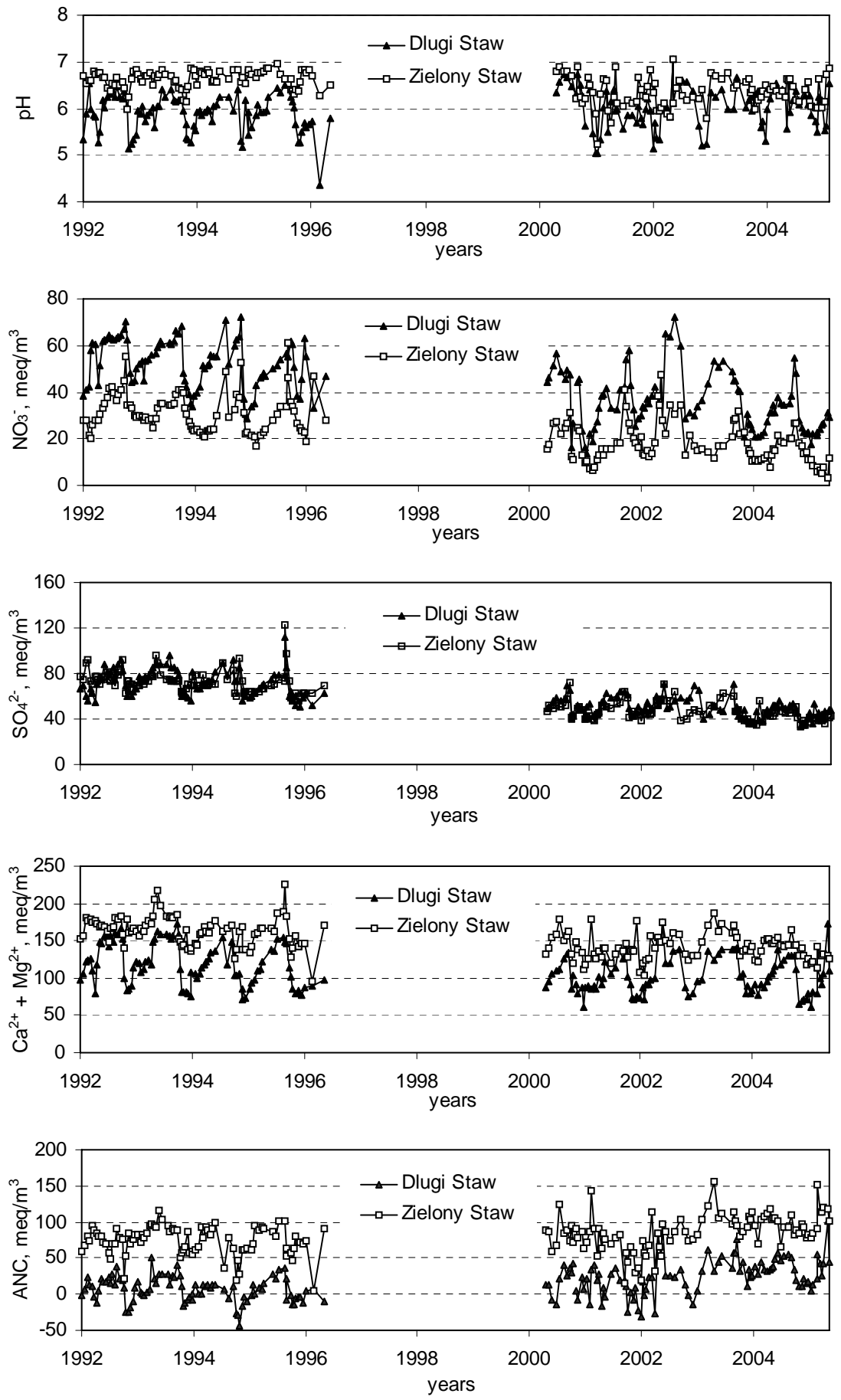

Fig. 6. Major chemical parameters in lake outflow from Dlugi Staw and Zielony Staw.

\subsection{Lake water chemistry}

The annual weighted mean concentrations of major chemical compounds in outflow water from the lakes are presented on Fig. 5. Concentrations of base cations and ANC were higher in discharge from Zielony Staw than from Dlugi Staw. The $\mathrm{SO}_{4}^{2-}$ concentrations are similar, reflecting similar deposi- tion of $\mathrm{S}$, while $\mathrm{NO}_{3}^{-}$concentration is significantly higher in the runoff from Dlugi Staw. Since Zielony Staw is located about $112 \mathrm{~m}$ lower in altitude than Dlugi Staw, the spring melt season often starts earlier at Zielony Staw. Thus Dlugi Staw often shows higher $\mathrm{NO}_{3}^{-}$concentration, lower ANC and $\mathrm{pH}$ earlier at spring in comparison to Zielony Staw (Fig. 5). 
Table 4. Trends in water chemistry for the two Tatra lakes for the period 1992-2005.

\begin{tabular}{ccc}
\hline Parameter & $\begin{array}{c}\text { Median slope } \\
{\left[\mathrm{meq} / \mathrm{m}^{3} / \mathrm{yr}\right]}\end{array}$ & Significance level \\
& Dlugi Staw & \\
$\mathrm{Ca}^{2+}+\mathrm{Mg}^{2+}$ & -1.604 & $<0.01$ \\
$\mathrm{SO}_{4}^{2-}$ & -2.60 & $<0.01$ \\
$\mathrm{NO}_{3}^{-}$ & -2.03 & $<0.01$ \\
$\mathrm{ANC}^{-}$ & +2.16 & $<0.01$ \\
$\mathrm{H}^{+}(1992-1996)$ & +0.073 & n.s. \\
$\mathrm{H}^{+}(2001-2005)$ & -0.146 & n.s. \\
$\mathrm{H}^{+}(1992-2005)$ & -0.017 & $<0.01$ \\
\hline & Zielony Staw & \\
\hline $\mathrm{Ca}^{2+}+\mathrm{Mg}^{2+}$ & -2.03 & $<0.01$ \\
$\mathrm{SO}_{4}^{2-}$ & -2.72 & $<0.01$ \\
$\mathrm{NO}_{3}^{-}$ & -1.57 & $<0.01$ \\
$\mathrm{ANC}^{+}$ & +1.55 & $<0.01$ \\
$\mathrm{H}^{+}(1992-1996)$ & -0.026 & n.s. \\
$\mathrm{H}^{+}(2001-2005)$ & -0.007 & n.s. \\
$\mathrm{H}^{+}(1992-2005)$ & +0.019 & $<0.01$ \\
\hline
\end{tabular}

* n.s. - not significant

In addition to altitude differences, the Dlugi Staw catchment has less vegetation cover and steeper slopes. This results in shorter contact time of water within the Dlugi Staw catchment. Shorter residence time of water within the catchment means less time for physio-chemical water-soil interactions and is reflected in by lower base cation concentrations and lower ANC. Another factor is geological differences. Both catchments contain granitoids covered by moraine, but soils of the Zielony Staw catchment have on average higher base saturation (Rzychoń, 1998), which is probably caused by some intrusions of limestone located at the catchment border (Trafas, 1985). From a biological point of view, the shorter residence time of water within the catchment means less time or reduced possibility for nutrients such as $\mathrm{N}$ to be assimilated by plants and micro-organisms. Sparse vegetation cover will further amplify this effect. These are likely major factors in the generally higher leakage of $\mathrm{NO}_{3}^{-}$by runoff from Dlugi Staw in comparison to Zielony Staw.

The chemical composition of surface waters can be depicted as a mixing of distinct types of water (melt-water, rainwater and groundwater) in various proportions. Their proportions change depending on meteorological conditions and the course of biological and chemical processes in the catchment and water regions. As illustrated in Fig. 6 the seasonal variability of chemical parameters of surface waters is related to seasonal variability in meteorological conditions in the catchments each year. Therefore, seasonal periods can be distinguished when water of similar origin and chemical composition flow from the catchment to the surface waters (Rzychoń, 1998).
A comparison of the chemical composition of waters in the investigated lakes in the two monitoring periods indicated that in the period of 2000-2005 the differences in concentrations of some chemical parameters between the lakes was reduced, and there was greater irregularity in seasonal changes than in 1992-1996 (Fig. 6).

Concentrations of base cations, $\mathrm{SO}_{4}^{2-}$ and $\mathrm{NO}_{3}^{-}$, ions that play key roles in the acidification process decreased between 1992 and 2005 while ANC increased (Table 4). A more rapid decrease of base cations and $\mathrm{SO}_{4}^{2-}$ was observed in the water of Zielony Staw, while a more rapid increase in ANC and decrease in $\mathrm{NO}_{3}^{-}$concentration was recorded in Dlugi Staw.

Hydrogen ion concentrations decreased in Dlugi Staw but increased in Zielony Staw. The rates of change are very low, however, indicating only slight changes in the acidification of both lakes.

Mass balances of inputs and outputs for major ions were calculated for both catchments and measurement periods (Tables 5 and 6). Dry deposition was assumed to be $20 \%$ of wet deposition (Lydersen et al., 1997; Rzychoń, 1998). The runoff coefficient (runoff/precipitation) for both lakes was assumed to be 0.86 (Łajczak, 1988). The comparison of the mass balances for the measurement period 2001-2005 with those from 1992-1996 showed an increase of approximately $15 \%$ in $\mathrm{N}$ retention in both catchments: in 2001-2005 about $70 \%$ and $44 \%$ of $\mathrm{N}$ was retained by the catchments of Zielony and Dlugi Staw, respectively, in comparison to 55\% and $28 \%$ in $1992-1996$.

The retention of $\mathrm{S}$ changed only slightly; it decreased by $4 \%$ in Zielony Staw and by $8 \%$ in Dlugi Staw (Tables 5 and 6). The results show higher retention of both $\mathrm{S}$ and $\mathrm{N}$ in Zielony Staw as compared to Dlugi Staw. Nitrate concentrations in both lake outflows declined between 1994 and 2004.

Interpretation of these mass balance calculations in the study catchments requires caution due to the large variability in meteorological conditions. In order to reduce potential inaccuracy a mass balance made for two years of similar hydrological regime was taken for comparison, i.e. 1996 (precipitation total $-1673 \mathrm{~mm}$ ) and 2002 (precipitation total $-1712 \mathrm{~mm}$ ). The observed tendencies were similar to those obtained while comparing averages from two testing periods, i.e. decrease of sulphur retention and increase of nitrogen retention by both catchments (Table 6)

\section{Discussion}

Polish and European data (EMEP, 2005) indicate a reduction in $\mathrm{S}$ and $\mathrm{N}$ emissions between 1992 and 2005. Monitoring of the deposition in Polish Tatra Mountains showed a distinct decrease in $\mathrm{S}$ deposition but no significant change in $\mathrm{N}$ deposition (Table 5). At the same time visible changes in the chemistry of lake outflows were observed. Concentration of $\mathrm{SO}_{4}^{2-}$ decreased (Fig. 6), following the drop of concentration in precipitation. Sulphate mass balances show diminishing $\mathrm{S}$ 
Table 5. Annual fluxes (meq/ $\left.\mathrm{m}^{2} / \mathrm{yr}\right)$ of N- and S-compounds in the two Tatra lakes, Dlugi Staw and Zielony Staw, in the years $1992-1996$ and 2001-2004.

\begin{tabular}{lcccccccc}
\hline & \multicolumn{4}{c}{ Zielony Staw } & \multicolumn{3}{c}{ Dlugi Staw } \\
\hline & \multicolumn{2}{c}{$\mathrm{SO}_{4}^{2-}$} & \multicolumn{2}{c}{$\mathrm{NO}_{3}^{-}+\mathrm{NH}_{4}^{+}$} & \multicolumn{2}{c}{$\mathrm{SO}_{4}^{2-}$} & \multicolumn{2}{c}{$\mathrm{NO}_{3}^{-}+\mathrm{NH}_{4}^{+}$} \\
\hline & $1992-1996$ & $2001-2004$ & $1992-1996$ & $2001-2004$ & $1992-1996$ & $2001-2004$ & $1992-1996$ & $2001-2004$ \\
\hline Input (dry + wet) & 96.5 & 86.2 & 90.1 & 113.0 & 96.5 & 86.2 & 90.1 & 113.0 \\
Output & 83.3 & 77.9 & 41.0 & 33.9 & 85.3 & 82.9 & 64.9 & 62.8 \\
Input-Output & 13.2 & 8.3 & 49.1 & 79.1 & 11.2 & 3.3 & 25.2 & 50.2 \\
Leakage (\%) & 86.3 & 90.4 & 45.5 & 30.0 & 88.4 & 96.2 & 72.0 & 55.6 \\
Retention \% & 13.7 & 9.6 & 54.5 & 70.0 & 11.6 & 3.8 & 28.0 & 44.6 \\
\hline
\end{tabular}

Table 6. Annual fluxes (meq/ $/ \mathrm{m}^{2} / \mathrm{yr}$ ) of N- and S-compounds in the two Tatra lakes, Dlugi Staw and Zielony Staw, in the years 1996 and 2002.

\begin{tabular}{lcccccccc}
\hline & \multicolumn{3}{c}{ Zielony Staw } & \multicolumn{4}{c}{ Dlugi Staw } \\
\hline & \multicolumn{2}{c}{$\mathrm{SO}_{4}^{2-}$} & $\mathrm{NO}_{3}^{-}+\mathrm{NH}_{4}^{+}$ & \multicolumn{2}{c}{$\mathrm{SO}_{4}^{2-}$} & \multicolumn{2}{c}{$\mathrm{NO}_{3}^{-}+\mathrm{NH}_{4}^{+}$} \\
\hline & 1996 & 2002 & 1996 & 2002 & 1996 & 2002 & 1996 & 2002 \\
\hline Input (dry + wet) & 120.7 & 70.3 & 105.8 & 92.0 & 120.7 & 70.3 & 105.8 & 92.0 \\
Output & 102.2 & 75.3 & 53.5 & 39.9 & 100.7 & 79.2 & 75.7 & 62.8 \\
Input-Output & 18.5 & -5.0 & 52.4 & 52.1 & 20.0 & -8.9 & 30.2 & 32.6 \\
Leakage (\%) & 84.6 & 107.1 & 50.5 & 43.4 & 83.5 & 112.6 & 71.5 & 64.6 \\
Retention \% & 15.4 & $\sim 0$ & 49.5 & 56.6 & 16.5 & $\sim 0$ & 28.5 & 35.4 \\
\hline
\end{tabular}

retention in both catchments, which may be due to export of stored $\mathrm{S}$ compounds accumulated in soil when the deposition was higher. In some cases, release of stored $\mathrm{S}$ can result in a delay in decrease of $\mathrm{SO}_{4}^{2-}$ in surface water despite distinct reductions in $\mathrm{S}$ deposition, as was seen in Virginia, USA (Skjelkvåle, 2005). The granite bedrock in the research area contains only small amounts of $\mathrm{S}$ in the form of very insoluble $\mathrm{BaSO}_{4}$ (Oleksynowa, 1970) and, therefore, it is unlikely that warmer temperatures will cause significant increase in sulphate concentration in water due to increased weathering.

Base cations decreased in both lakes. Such a decrease is rather common in sites where the recovery caused by reduction of acid deposition takes place. Base cations leave the catchments accompanying anions of strong acids in quantities set by stoichiometry (Galloway et al., 1983). During the recovery the acid deposition decline can also cause reduction of base cations concentrations due to diminishing weathering rates and/or increase of base cations uptake (Veselỳ et al., 2002). Diminishing base cations concentrations slows recovery of surface waters.

Even though concentrations of $\mathrm{N}$ compounds in precipitation did not decrease, $\mathrm{NO}_{3}^{-}$concentrations in both lakes distinctly declined. Taking into account data from literature (Kopáček et al., 2005) it can be expected that $\mathrm{NH}_{4}^{+}$deposited into both catchments is mostly assimilated by plants and/or oxidised by micro-organisms producing nitrate. As a result, in-lake concentrations of ammonium are close to zero. Also, this rather strong demand for ammonium by plants and micro-organisms prevents increasing in sorption of ammonium in soil. The $\mathrm{N}$ mass balances showed large increases (average 15\%) in retention at both sites. It is not possible to determine if the increased $\mathrm{N}$ retention occurred in the lakes themselves or in the catchments. Since physical retention of nitrate by soil is unlikely, the most likely explanation of increased $\mathrm{N}$ retention is increased $\mathrm{N}$ uptake by terrestrial vegetation and storage as organic $\mathrm{N}$ (i.e. immobilisation) and/or increased denitrification rates. Both the progress in recovery from acidification and increase in temperature should cause the denitrification rates to be higher. However, denitrification was found to cause only a minor loss of deposited $\mathrm{N}$ in upland catchments (Curtis and Simpson, 2001). Thus, N retention is most likely due to immobilisation processes in soil.

Both reduced acidification and climate warming may be responsible for the increased $\mathrm{N}$ retention. An increase of temperature and some changes in the precipitation pattern, along with a simultaneous decrease in acid deposition (mainly sulphur), took place in the study period, causing a reversal in the trends of acidification. 
Table 7. Criteria for stages of nitrogen saturation based on monthly average $\mathrm{NO}_{3}^{-}$concentrations in runoff (Stoddard and Traaen, 1995).

\begin{tabular}{ll}
\hline Stage & Criteria \\
\hline 0 & $\geq 3$ months in the growing season with $\mathrm{NO}_{3}^{-} \leq 3 \mathrm{meq} / \mathrm{m}^{3}$ and peak value $<20 \mathrm{meq} / \mathrm{m}^{3}$ \\
1 & $1-2$ months in the growing season with $\mathrm{NO}_{3}^{-} \leq 3 \mathrm{meq} / \mathrm{m}^{3}$ or $\geq 3$ months in the growing season with $\mathrm{NO}_{3}^{-} \leq 3 \mathrm{meq} / \mathrm{m}^{3}$ and \\
& $\begin{array}{l}\text { peak value } \geq 20 \mathrm{meq} / \mathrm{m}^{3} \\
2\end{array}$ \\
3 & $\begin{array}{l}\text { No months with } \mathrm{NO}_{3}^{-} \leq 3 \mathrm{meq} / \mathrm{m}^{3} \text { and } \geq 3 \text { months in the growing season with } \mathrm{NO}_{3}^{-}<50 \mathrm{meq} / \mathrm{m}^{3} \\
<3 \text { months with } \mathrm{NO}_{3}^{-}<50 \mathrm{meq} / \mathrm{m}^{3}\end{array}$ \\
\hline
\end{tabular}
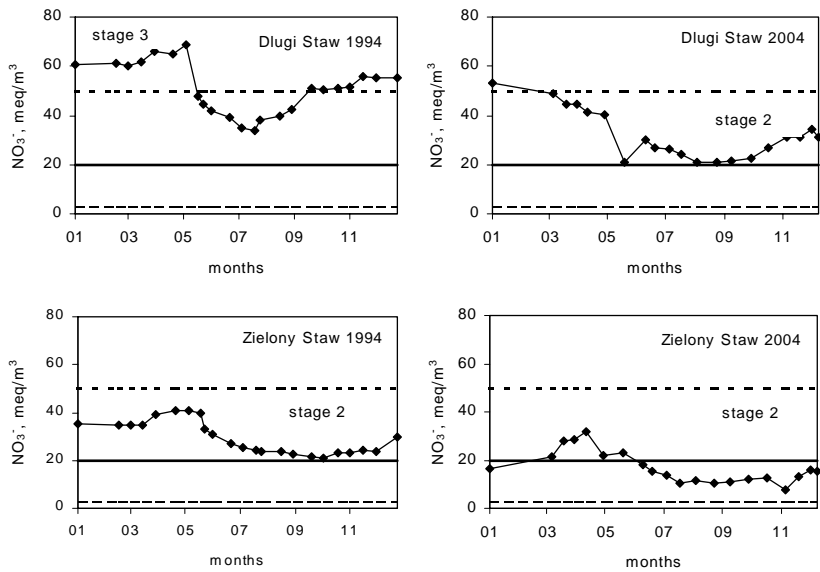

Fig. 7. Seasonal patterns of $\mathrm{NO}^{3-}$ concentrations $\left(\mathrm{meq} / \mathrm{m}^{3}\right)$ in lake outflow from Zielony Staw and Dlugi Staw. Stages of N saturation (following the criteria of Stoddard and Traaen, 1995) are indicated.

Additional factors favourable to the $\mathrm{N}$ uptake by plants are an increasing proportion of ammonium $\mathrm{N}$ in precipitation (Fig. 3) and hydrological changes (Fig. 2) resulting from more variability in monthly precipitation in later years, which should reduce the share of surface flow in the runoff, and consequently increase water residence time in the catchment soil as well as increase chances for an effective uptake of $\mathrm{N}$ by vegetation.

In the case of Tatra Mountains there are insufficient data to confirm this hypothesis. Studies comparing plant distributions around the research area, based on the analysis of photographs taken in 1965 and 1999, indicated a succession of forest complexes and overgrowing of clearances and high-mountain pastures. It was noted that within 34 years the area covered with a dwarf pine increased by $28 \%$. The changes are closely connected with the discontinuance of sheep-grazing after the establishment of the Tatra National Park in 1954. The main conclusion from this study is that tree and scrub communities in the Tatra Mountains are currently returning to their natural ecological states (Wężyk and Guzik, 2004). It is difficult, however, to apply the conclusions of this work directly to the catchment of the investigated lakes. Due to their unfavourable location the whole
Dlugi Staw catchment and the major part of Zielony Staw catchment could not have been subject to intense grazing.

The analysis of changes in the wood tissue of beech trees in Tatra Mountains in years 1931-1992 showed decreases in the annual ring width in 1960-1965 and 1970-1980. The first period was likely due to very hard winters while the second might have been caused by air pollution, as has been seen in other species (Niedzielska et al., 2002). At present, beech trees are growing well in the Tatra Mountains area. Thus, acid deposition and cold temperatures could have reduced $\mathrm{N}$ retention.

Changes in the seasonal and long-term patterns of surface water $\mathrm{NO}_{3}^{-}$concentrations reflect the changes in $\mathrm{N}$ cycling that occur in the catchment. The seasonal variability of chemical parameters of surface waters corresponds to stages of terrestrial N saturation (Aber et al., 1989; Stoddard, 1994). In Fig. 7 seasonal $\mathrm{NO}_{3}^{-}$concentrations in both lakes in 1994 and 2004 are presented. Based on the criteria defined by Stoddard and Traaen (1995) (Table 7) the investigated lakes were assigned to specific N saturation classes. In 1994 the Dlugi Staw was close to the 3rd Stage and Zielony Staw was in the 2nd Stage of $\mathrm{N}$ saturation. This means that both catchments were in chronic stages of N-saturation. In 2004, Dlugi Staw moved from Stage 3 to Stage 2. Zielony Staw also showed the decline in $\mathrm{NO}_{3}^{-}$concentration and is now close to reaching Stage 1 of $\mathrm{N}$ saturation. These changes are not explained by changes in $\mathrm{N}$ deposition, which, as showed earlier, does not indicate a downward tendency.

Despite the fact that observed trends in the Tatra Mountains are quite rare, they are not unique. The Lange Bramke stream in Germany showed clear change in stage of $\mathrm{N}$ saturation from stage 1 in 1970 to stage 3 in 1985 and back to stage 1 in 1999 (Wright et al., 2001). These changes are not explained by changes in $\mathrm{N}$ deposition. A comparison of concentrations of $\mathrm{SO}_{4}^{2-}, \mathrm{NO}_{3}^{-}, \mathrm{Cl}^{-}, \mathrm{Ca}^{2+}$ and $\mathrm{pH}$ at 432 mountain streams localities in the Czech Republic sampled at a time of high (1984-1986) and relatively low (1996-2000) acidic deposition showed a decrease of $\mathrm{NO}_{3}^{-}$of up to $60 \%$ in stream waters with $\mathrm{pH} \leq 6$ while the decrease of $\mathrm{N}$ emissions in Central Europe was only about $35 \%$ (Veselý et al., 2002). The difference in $\mathrm{NO}_{3}^{-}$concentrations between the two periods was probably enhanced by (a) an increase of 
$\mathrm{NO}_{3}^{-}$leaching due to enhanced mineralization of forest floor resulting from forest damage and deforestation in the mid1980s (b) by higher uptake of $\mathrm{N}$ under less acidic stress in the late-1990s.

Also in Austrian mountain lakes (Sammaruga-Wögrath et al., 1997) an increasing concentration of $\mathrm{SO}_{4}^{2-}$ and a decreasing content of inorganic $\mathrm{N}$ over a period of 10 years were observed. The changes were inverse to the deposition changes recorded in this area and attributed to increased weathering rates and increased biological activity resulting from climate warming. Sickman et al. (2001) suggests that if current trends towards warmer air temperatures continue, $\mathrm{N}$-retention will increase in high elevation catchments in the Sierra Nevada, USA. Rogora (2003) indicates the same for lakes in the Italian Alps. The observed response of the Tatra catchments is consistent with these expectations. The recent research activities carried out in the Karkonosze Mountains lakes, where acid deposition is (and was in the past) much higher than in the case of the Tatras, indicate a very significant $\mathrm{N}$ retention, about $85 \%$ (Rzychoń, unpublished data). It can also be expected that the Karkonosze catchments should show further advancement of this process.

\section{Conclusions}

Acid deposition in Polish Tatra Mountains decreased significantly during the 14 years mainly due to a distinct decrease in sulphate deposition. Despite the lack of clear trends in nitrogen deposition, a significant drop in $\mathrm{N}$ concentrations was observed in the investigated lakes. Significant increases (about 15\% in both catchments) in the retention of nitrogen compounds also occurred. An improvement in nitrogen saturation status in both catchments was observed. This phenomenon probably resulted from small changes of many factors (mainly assimilation by plants and microbes) caused mostly by the decreasing acidification of the environment and warmer temperatures.

Acknowledgements. This work was financially supported by Polish Ministry of the Environment and the National Fund for Environmental Protection and Water Management. We appreciate the assistance of M. and M. Kot from the Tatra Mountain National Park, who performed field work over many years. We thank Norwegian Institute for Water Research (NIVA) and Norwegian Institute for Air Research (NILU) for fruitful cooperation in 1992-1996. Last but not least we would like to thank 2 anonymous reviewers for many helpful comments and critiques, which improved the manuscript.

Edited by: P. Dillon and R. F. Wright

\section{References}

Aber, J. D., Nadelhoffer, K. J., Steudler, P., and Melillo, J. M.: Nitrogen saturation in northern forest ecosystems, BioScience, 39, 378-386, 1989.

Curtis, C. and Simpson, G. (Eds.): Summary of research under DETR contract "Acidification of freshwaters: the role of nitrogen and the prospects for recovery" EPG/1/3/117, Executive Summary, Research Report no 79, Environmental Change research Centre, University College London, 49 pp., 2001.

Davies, J. J. L., Jenkins, A., Monteith, D. T., Evans, C. D., and Cooper, D. M.: Trends in surface chemistry of acidified UK Freshwaters, 1988-2002, Environ. Pollut., 137, 27-39, 2005.

Dillon, P. L., Skjelkvåle, B. L., Somers, K. M., and Torseth, K.: Coherent responses of sulphate concentration in Norwegian lakes; relationship with sulphur deposition and climate indices, Hydrol. Earth Syst. Sci., 7, 596-608, 2003, http://www.hydrol-earth-syst-sci.net/7/596/2003/.

EMEP: http://www.emep.int/index_data.html, last access: 20 February 2008, 2005.

Evans, C. D. and Monteith, D. T.: Natural and anthropogenic changes in the chemistry of six UK mountain lakes, Water, Air Soil Pollut., 2, 33-46, 2002.

Galloway, J. N., Norton, S. A., and Church, M. R.: Freshwater acidification from atmospheric deposition of sulphuric acid: A conceptual model, Environ. Sci. Technol., 17, 541-545, 1983.

Gunn, J. M. (Ed.): Restoration and recovery of an industrial region, Springer, New York, 1985.

Helsel, D. R. and Hirsch, R. M.: Statistical Methods in Water Resources. Studies in Environmental Science 49, Elsevier Science Publishers, p. 522, 1992.

IMGW (Institute of Meteorology and Water Management): available at: http://www.imgw.pl, last access: 20 February 2008, 2005.

Kopáček, J., Stuchlik, E., and Wright, R. F.: Long-term trends and spatial variability in nitrate leaching from alpine catchment-lake ecosystems in the Tatra Mountains (Slovakia-Poland), Environ. Pollut., 136, 89-101, 2005.

Kownacki, A., Galas, J., Dumnicka, E., and Mielewczyk, S.: Invertebrate communities in permanent and temporary high mountain lakes (Tatra Mts), Annals Limnol., 36(3) 181-188, 2000.

Łajczak A.: Precipitation and runoff in the polish Tatra in the light of long-term measurements, Geographic Journal LIX, 2, 137170, 1988 (in Polish).

Lydersen, E., Rzychoń, D., Worsztynowicz, A., Tørseth, K., Hanssen, J. E., Mill, W. A., Kot, M., Henriksen, A., and Wathne, B. M.: Critical loads of acidity to lakes in the Polish Tatra Mountains, Final report, Report 44/1997, NIVA, Oslo, 49 pp., 1997.

Niedzielska, B., Wilczyñski, S., and Wasik, R.: The analysis of changes in the wood tissue of the beech (Fagus silvatica) in Tatra mountains in years 1931-1992, in: Przemiany œrodowiska przyrodniczego Tatr. PTPNoZ. Zakopane-Krakow, 209-212, 2002 (in Polish).

Niedźwiedź, T.: Long-term variability of air temperature and precipitation in the Tatra Mountains. Proceedings of the 1st Polish Conference on The Tatra National Park Nature and Man, Present state and perspectives of future Tatra investigation, Zakopane, 69 October 1995, 161-163, 1996.

Niedźwiedź, T.: Summer temperature patterns over the Tatra Mountains (Central Europe) from 1550 to 2004, Presen- 
tation at The 5th Annual Meeting of the European Meteor Society, 12-16 September 2005, Utrecht, The Netherlands, available at: http://www.cosis.net/abstracts/EMS05/ 00422/EMS05-A-00422.pdf, last access: 20 February 2008, 2005.

Oleksynowa, K.: Geochemical characterization of the waters in the Tatra Mountains, Acta Hydrobiologica, 12(1), 100 pp., 1970 (in Polish).

Otrębska-Starklowa, B., Trepińska, J., Niedźwiedź, T., and Bednarz, Z.: Trends of climatic change in the Polish Tatra Mountains, Proceedings of the 1st Polish Conference on The Tatra National Park Nature and Man, Present state and perspectives of future Tatra investigation, Zakopane, 6-9 October 1995, 168-171, 1996 (in Polish).

Rogora, M., Mosello, R., and Arisci, S.: The effect of climatic warming on the hydrology of alpine lakes, Water Air Soil Pollut., 148, 347-361, 2003.

Rzychon, D.: Impact of acid precipitation on acidification of the Tatra lakes, Wydawnictwo Uniwersytetu Śląskiego, Katowice, 132 pp., 1998 (in Polish).

Sickman, J. O., Leydecker, A., and Melack, J. M.: Nitrogen mass balances and abiotic controls on $\mathrm{N}$ retention and yield in highelevation catchments of the Sierra Nevada, California, United States, Water Resour. Res., 37(5), 1445-1461, 2001.

Skiba, S.: Studia nad glebami wytworzonymi w różnych piętrach klimatyczno-roślinnych krystalicznej czȩści Tatr Polskich, Roczniki Gleboznawcze T. XXVIII, Nr 1, Warszawa 1977, 205-239, 1977 (in Polish).

Skjelkvåle, B. L., Stoddard, J., Jeffries, D., Tørseth, K., Høgåsen, T., Bowman, J., Mannio, J., Monteith, D., Mosello, R., Rogora, M., Rzychoń, D., Veselý, J., Wieting, J., Wilander, A., and Worsztynowicz, A.: Regional scale evidence for improvements in surface water chemistry 1990-2001, Environ. Pollut., 137, 165-176, 2005.

Sommaruga-Wögrath, S., Koinig, K. A., Schmidt, R., Sommaruga, R., Tessadri, R., and Psenner, R.: Temperature effects on the acidity of remote alpine lakes, Nature, 387, 64-67, 1997.

Stoddard, J. L.: Long-Term Changes in Watershed Retention of Nitrogen, Its Causes and Aquatic Consequences, Advances in Chemistry Series No. 237, American Chemical Society, Washington, D.C., 223-284, 1994.
Stoddard, J. L. and Traaen, T. S.: The stages of nitrogen saturation: Classification of catchments included in "ICP on waters", in: Mapping and modeling of critical loads for nitrogen - a workshop report, edited by: Horning, M., Sutton, M. A., and Wilson, R. B., 69-76, Proceedings of Grange-over-Sands Workshop, 24-26 October 1994, Institute of Terrestrial Ecology, Edinburgh, UK, 1995.

Stoddard, J. L., Jeffries, D. S., Lükewille, A., Forsius, M., Mannio, J., and Wilander, A.: Environmental chemistry - is acidification still an ecological threat?, Reply, Nature, 407, 857-858, 2000.

Szafer, W.: The Tatra National Park, Zakład Ochrony Przyrody PAN Kraków, 675 pp., 1962 (in Polish).

Trafas, K.: Atlas of the Tatra National Park, Wojskowe Zakady Kartograficzne, Zakopane - Kraków, 1985.

Veselý, J., Hruska, J., Norton, S. A., and Johnson, C. E.: Trends in the chemistry of acidified Bohemian lakes from 1984 to 1995. I. Major solutes, Water Air Soil Pollut., 108(1-2), 107-127, 1998.

Veselý, J., Majer, V., and Norton, S. A.: Heterogeneous response of central European streams to decreased acidic atmospheric deposition, Environ. Pollut., 120(2), 275-281, 2002.

Veselý, J., Majer, V., Kopáček, J., and Norton, S. A.: Increasing temperature decreases aluminium concentrations in Central European lakes recovering from acidification, Limnol. Oceanogr., 48(6), 2346-2354, 2003.

Wężyk, P. and Guzik, M.: The use of "Photogrammetry-GIS" (PGIS) for the analysis of changes in the Tatra Mountains natural Environment, in: A message from the Tatra, edited by: Widacki, W., Bytnerowicz, A., and Riebau, A., Geographical Information Systems and Remote Sensing in Mountain Environmental Research, Institute of Geography and Spatial Management Jagiellonian University, USDA Forest Service, Kraków, Poland, Riverside, California, USA, 31-46, 2004.

Wright, R. F., Alewell, C., Cullen, J. M., Evans, C .D., Marchetto, A., Moldan, F., Prechtel, A., and Rogora, M.: Trends in nitrogen deposition and leaching in acid- sensitive stream in Europe, Hydrol. Earth Syst. Sci., 5, 299-309, 2001, http://www.hydrol-earth-syst-sci.net/5/299/2001/. 